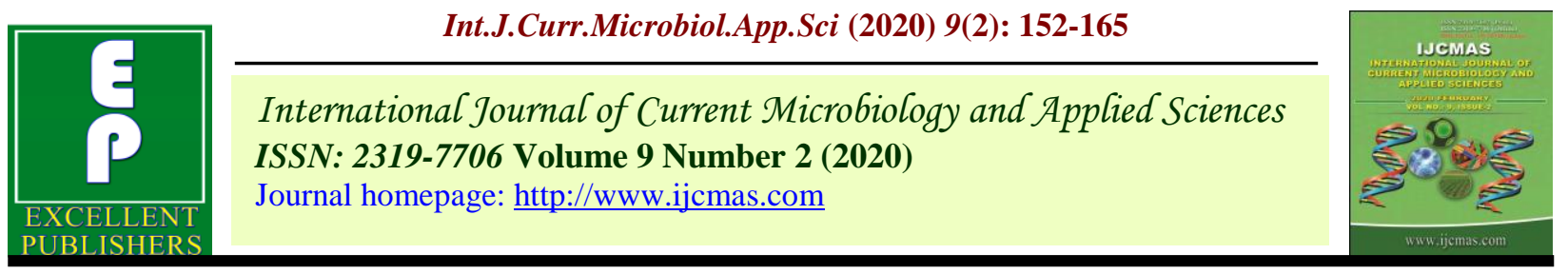

Review Article

https://doi.org/10.20546/ijcmas.2020.902.019

\title{
Enhancement of Plant Growth by Using PGPR for a Sustainable Agriculture: A Review
}

\author{
Anshu Kumar ${ }^{1 *}$, Ritesh Kumar ${ }^{1}$, Mamta Kumari² and Suraj Goldar ${ }^{1}$ \\ ${ }^{1}$ Department of Plant Pathology, Bidhan Chandra Krishi Viswavidyalaya, Mohanpur, West \\ Bengal, India \\ ${ }^{2}$ Department of Soil Science and Agricultural Chemistry, Bihar Agriculture College, Bihar \\ Agricultural University, Sabour, Bihar, India \\ *Corresponding author
}

Keywords

Biotic and abiotic stress, PGPR, Sustainable

Article Info

Accepted:

05 January 2020

Available Online:

10 February 2020

\section{A B S T R A C T}

Biotic and abiotic stresses exert a serious impact on crop productivity throughout the world. The alternate strategy is to introduce tolerant microbes into plants under stress conditions. Intensive research attempts are underway to improve plant growth, enhance tolerance level against these stresses and protect plants by using plant growth promoting rhizobacteria (PGPR) which have a great potential for sustainable crop production. PGPR play a direct role in maintaining better plant health by nitrogen fixation, phosphate solubilisation, phytohormone production etc. and indirectly by siderophore production, antibiotic production, ACC deaminase activity, Induced Systemic resistance etc. The microbes provide plants resistance to stress by enhancing the activity of the antioxidant enzymes and other nonenzymatic antioxidants.

\section{Introduction}

Our nature is embedded with full of treasures with not only expensive products like gold, diamond, minerals etc. but also with some priceless things which are having literally even more value than all of this. Apart from these things which are so important for the survival on this earth like air, water and soil, nature is aiding things which are equally important for a sustainable future. Yes, it is in fact beyond our imagination that even small organisms surviving in soil can be useful for the plants. There are group of natural entities like beneficial soil microbial flora which are dwelling in the rhizosphere and on the surface of the plant roots which impose overall wellbeing of the plants are categorized as Plant Growth Promoting Rhizobacteria (PGPR). Researchers are studying these microbes for the past 30 years to understand the mechanics and usefulness employed by these PGPR to 
support plant growth. The plant-beneficial rhizobacteria may decrease the global dependence on hazardous agricultural chemicals which destabilize the agroecosystem. Microbial populations are ubiquitous and are present in diverse ecological niches, including extreme environments, present in both lithosphere and hydrosphere, where they can thrive easily and their metabolic abilities play a significant role in geochemical nutrient cycling (Aeron et al., 2011).

Agriculture is hit badly by both biotic and abiotic factors. Plant pathogens, such as bacteria, viruses, fungi, and parasites heavily damage the yield. The annual agriculture yield losses due to the disease cause by these pathogens are at least 30\% globally (Fisher et al.,2012). Among all, two-third of total diseased plants is infected by fungi. Agricultural land management, greater use of chemicals including fertilizers, judicious and safe pesticides and herbicides uses, more farm mechanization, greater use of transgenic crops are some of the solutions to boost the yield. But these solutions are effective in short time because we have limited number of resources. The fertilizers will affect our environment adversely. The farm mechanization is not acceptable to everyone due to its high cost. The use of transgenic crops is restricted due to some ethical concerns and resistance breakdown. Thus, we need a long term, safe, sustainable, eco-friendly biological solutions. Expanded use of PGPR is one of the ultimate solutions in our hand which will complete all the mentioned criteria. We should praise our nature for gifting us with such a noble creature.

\section{Rhizosphere and associated communities}

Bacterial populations are widely distributed over the soil and some adheres with the plant's roots, interact with it. The term 'rhizosphere' was coined by Hiltner (1904) who describes it as a zone which is dominated by root exudates. Later on, it was defined as that portion of the soil which is specially affected by plant roots and/or in association with roots and roots hairs, and plant-produced materials (Andrade et al., 1997). This area cover the soil packed by the roots, extending a few millimetres from the root surface and can consist of the plant root epidermal layer (Bringhurst et al., 2001). Further the definitions were updated that it is the modulation of root's parameters like physical, chemical and biological with respect of growth and activity (Sivasakthi et al., 2014). The bacterial populations in the rhizosphere are 100-1000 times higher than the rest of the soil. The probability of finding these bacteria is higher in the rhizosphere because they possess unique ability to alter their metabolic activities and consumes the roots exudates efficiently. Also, $15 \%$ of the root surface is covered by microbial populations belonging to several bacterial species (Govindasamy et al., 2011; Jha et al., 2010). Plant photosynthetic product (about 5 to $30 \%$ ) is secreted by roots in form of different sugars which in turn is utilized by microbial populations (Glick, 2014). Subsequent metabolic activities of these bacteria in the rhizosphere accelerate mineral nutrient transport and uptake by plant roots (Glick, 1995). The rhizosphere serves as an ecological niche for PGPR. Generally, about $2-5 \%$ of rhizosphere bacteria are PGPR (Antoun and Prevost, 2006; Jha et al., 2010; Sgroy et al., 2009; Siddikee et al., 2010).

Due to accumulation of variety of plant exudates, such as amino acids and sugars, the zone is acquainted with nutrients as compared to rest of soil providing source of energy and nutrients for microbes (Gray and Smith, 2005). A range of microorganisms including bacteria, algae, fungi, protozoa and actinomycetes colonize the roots of plants. 
They live independently or in association with another organism. A popular symbiotic association exist between fungi and roots of plants (mycorrhizal) which facilitate the plant to absorb more water and nutrients by increasing the root surface area (Nadeem et al., 2014), the microorganisms in turn get shelter.

\section{Plant Growth Promoting Rhizobacteria (PGPR)}

The bacteria that colonized the root, improve plant growth and yield by the addition of some growth factors and hormones are called as PGPR (Kloepper and Schroth, 1978). A rhizosphere bacterium is considered to be a PGPR when it affects the plant in a positive way upon inoculation, thus showing a different active characteristic to the existing rhizosphere communities. In 1998, Bashan and Holguin, revised the definition because there are bacteria which demonstrate a positive interaction over the plant although they are outside the rhizosphere environment. During the Fourth International Congress of Bacterial Plant Pathogens, conducted in France, the importance of rhizobacteria for the plant health was showed by Kloepper and Schroth (1978). PGPRs can act as solid tools for the sustainable agriculture and can produce a new era for the management of diseases.

\section{Classification of PGPR}

PGPRs are associated differently with respect to the plant root cells, either outside the root i.e. in rhizosphere, on the rhizoplane or can be confined to the spaces between cells of the root cortex, or inside the roots particularly in the root cortex and thus can be grouped into extracellular plant growth promoting rhizobacteria (ePGPR) and intracellular plant growth promoting rhizobacteria (iPGPR) respectively (Martinez-Viveros et al., 2010).
Agrobacterium, Arthrobacter, Azotobacter, Azospirillum, Bacillus, Burkholderia, Caulobacter, Chromobacterium, Erwinia, Flavobacterium, Micrococcous, Pseudomonas and Serratia belongs to ePGPR (Gray and Smith, 2005). Endophytes and Frankia species belongs to iPGPR. Endophytes include large number of soil bacterial genera such as Allorhizobium, Azorhizobium, Bradyrhizobium, Mesorhizobium and Rhizobium of the family Rhizobiaceae that are closely associated in the formation of root nodules (Wang and Maetinez-Romero, 2000). Among all the recognised genera of PGPR, Bacillus and Pseudomonas predominates (Podile and Kishore, 2006).

\section{Mechanism of PGPR}

PGPR affect plant growth in two different ways, indirectly or directly (Figure 1). Indirect mechanisms, as the name suggest are those that do not affect the plant in a straight way and happen outside the plant, while direct mechanisms are those that occur inside the plant and directly involved in the plant's metabolism (Antoun and Prevost, 2006; Glick, 1995; Siddik et al., 2010; Vessey, 2003). Biological nitrogen fixation, phosphate solubilization, phytohormone and siderophore production are some of the direct whereas production of defence enzymes and antibiotic, modulation of plant stress markers, induce systemic resistance (ISR) and competition for the rhizosphere are some of the indirect mechanism .The direct mechanisms include those in which either the bacteria will produce the growth regulators, ultimately incorporate in plant system and thus affect the balance of plant growth regulators or they act as a sink of plant release hormones that will induce plant metabolism leading to the overall growth of the plant (Glick, 2014; Govindasamy et al., 2011). 


\section{Direct mechanism of PGPR}

\section{Nitrogen fixation}

Bacterial strains which are able to fix atmospheric nitrogen can be classified into two parts. The one which act symbiotically (root/legume association), got the specificity and infects the root of the plants to produce nodules e.g. Rhizobium strains. Other group of bacteria are free living which does not possess specificity (Oberson et al., 2013). Examples of such free-living nitrogen fixers include Azospirillum, Azotobacter, Burkholderia, Herbaspirillum, Bacillus, and Paenibacillus (Goswami et al., 2015; Heulin et al., 2002; Seldin, 1984; von der Weid et al., 2002). These free living nitrogen fixers although not closely associated with plants as they do not penetrate the root of plants but able to fix the nitrogen for better nitrogen absorption to the plants. This relationship is called as non-specific or loose symbiosis. The amount of nitrogen fixed ranges between 20 and $30 \mathrm{~kg}$ per hectare per year (Stacey et al., 1992). Azotobacter and Azospirillum are the most widely used species in agricultural trials. They are first reported in 1902 and are the most widely use strains till date (Bhattacharya and Jha, 2012). Application of Azotobacter chroococcum and Azospirillum brasilense inoculants in agriculture, especially in cereals has resulted in significant increases in crop yields (Oberson et. al., 2013).

Based on nitrogenase activity, Bacillus azotofxans, Bacillus macerans, and Bacillus polymyxa, were identified as nitrogen fixers, (Seldin et al., 1984). However, after reclassification, these organisms are now classified in Paenibacillus genus. Paenibacillus odorifer, Paenibacillus graminis, Paenibacillus peoriae, and Paenibacillus brasilensis have been described as nitrogen fixers (Heulin et al., 2002; von der Weid et al., 2002). Symbiotic nitrogen fixing bacteria such as rhizobia are closely assosciated with root hairs. The rhizobia and the nod factors (lipo-chitin oligosaccharides) interact to change the cell division processes in the root hair cells resulting in curling of the root hairs. The nod factors operate within these curled root hairs, leading to the formation of infection threads through which these rhizobia make their way to enter inside leguminous crops (Broughton et al., 2000; William et al., 2000) and are reported to possess nif gene cluster which are responsible to code for nitrogenase enzyme, a key enzyme involved in nitrogen fixation. These are widely use in biofertilizers for the past 20 years and are very important for agriculture (Goswami et al., 2015; Heulin et al., 2002).

\section{Phosphate solubilisation}

Despite abundant reserve of phosphorous, plant is unable to take these phosphorous directly. Plants are only able to absorb monoand dibasic phosphate which are the soluble forms of phosphate (Jha et al., 2012; Jha and Saraf, 2015). Hence, they are among the most limiting nutrients after nitrogen for the plants. The key mechanism of phosphate solubilization is based on production and secretion of organic acid by microbes i.e. PGPR (Han et al., 2006). Sugars (Glucose, fructose, mannitol and other form of carbohydrates) from root exudates are metabolized to produce organic acids by these noble creatures living in the rhizosphere (Goswami, 2014). The acids released by the micro-organisms has a property to act as a good chelators of divalent $\mathrm{Ca}$ cations or decrease the $\mathrm{pH}$ which facilitates the release of phosphates from insoluble phosphatic compounds (Pradhan and Shukla, 2006). Further, these microbes have the ability to release enzymes specially phosphatases (Tarafdar et al., 1988; Yadav and Tarafdar, 2003; Aseri et al., 2009) and phytases (Moughal et al., 2014) which bring about 
enzymatic reaction to transform the organic $\mathrm{P}$ into soluble forms of $\mathrm{P}$ through the process of mineralization (Figure 2). Since 1903, these microorganisms are known to act as a chief agent of phosphate solubilisation (Kucey et al., 1989).

\section{Phtyohormone production}

The soil microorganisms especially those residing in the rhizosphere are assosciated with production of phytohormones like auxins, gibberellins, cytokinins, ethylene, and abcisic acid (Arshad and Frankenberger, 1998). These phytohormones play an important role in plant growth and development process such as plant cell enlargement, division, and extension in both symbiotic and non-symbiotic associations of roots (Glick, 2014; Patten and Glick, 1996). Auxin basically impacts the growth and development of whole plant but as IAA is produced in the rhozospheric zone, it mainly affects the root system (Salisbury, 1994) by increasing its size and weight, branching number, and the surface area in contact with soil. Consequently, it accelerates the nutrient exchange process by the roots which strengthen nutrition balance and growth buildup of the plant (Ramos-Solano et al., 2008). L- tryptophan is known to be the precursor of IAA. Most of these PGPRs make use of Ltryptophan which is secreted in root exudates for the production of IAA through LTryptophan dependent pathway. Although some like Azospirillum brasilense, produces more than $90 \%$ of IAA through L-tryptophan independent pathway and remaining $10 \%$ IAA is produced by utilizing L-tryptophan. However, the exact mechanism and enzymes used for IAA synthesis by this route is still unrevealed (Jha and Saraf, 2015; Spaepen et al., 2007).

Pseudomonas, Azospirillum, Bacillus, Proteus, Klebsiella, Escherichia,
Pseudomonas, and Xanthomonas includes some of the microorganism which are responsible for cytokinins production (Maheshwari et al., 2015). Zeatin and kinetin are two major Adenine-type cytokinins, in which N6 position of adenine is substituted with an isoprenoid and an aromatic side chain respectively. Zeatin can be synthesized in two different pathways: the tRNA pathway and the adenosine monophosphate (AMP) pathway.

Seed germination, stem elongation, flowering, and fruit setting are some of the function of gibberellic acid (Hedden and Phillips, 2000). Rhizobium meliloti, Azospirillum sp., Acetobacter diazotrophicus, Herbaspirillum seropedicae and Bacillus sp. are some of the important microorganism capable of producing gibberellic acid.

\section{Indirect mechanism}

\section{Siderophore production}

Iron is quite abundant in soils but is frequently unavailable for plants or soil micro-organisms. $\mathrm{Fe}^{+3}$ is the oxidized form that reacts to form insoluble oxides and hydroxides such as $\mathrm{Fe}(\mathrm{OH}) 3$ which are difficult to be utilize by the plants and microorganisms. Siderophores $(\mathrm{sid}=$ iron, phore $=$ bearer) are low-molecular weight $(<1 \mathrm{kDa})$, high affinity iron chelating compounds which functions to deliver iron to the plant cell (Hider and Kong, 2010).

Pseudomonas fluorescens and Pseudomonas aeruginosa release pyochelin and pyoverdine type of siderophores (Haas and Defago, 2005). These siderophores producing microorganism improve Fe uptake and hinder the growth of pathogen (generally fungi) as a result of competition for scavenging iron (Shen et al., 2013). 


\section{Defence enzymes}

Different strains of PGPR possess the ability to secrete cell wall degrading enzymes like $\beta$ 1,3-glucanase, chitinase, cellulase, lipase and protease which degrade the cell wall of fungi (Chet and Inbar, 1994). Chitinase breaks the chitin, second largest abundant organic molecule and a major component of the fungal cell wall. Another defence enzyme, $\beta$ 1,3-glucanase is produce by Bacillus cepacia which destroys the cell walls of $R$. solani, $P$. ultimum, and Sclerotium rolfsii (Compant et al., 2005). The mycelia of the fungal pathogens Rhizoctonia solani and Fusarium oxysporum co-inoculated with an effective biocontrol strain Serratia marcescens B2 alter hyphal proliferation resulting in swelling, curling or bursting of the hyphal cell (Someya et al., 2000).

\section{Antibiotic production}

Antibiotic produce by PGPR act as good biocontrol. These antibiotics includes 2,4Diacetyl Phloroglucinol (DAPG), Phenazine1-carboxylic acid (PCA),Phenazine-1carboxamide (PCN), Pyoluteorin(Plt), Pyrrolnitrin (Prn), Kanosamine, Zwittermycin-A, Aerugine, Rhamnolipids, Pseudomonic acid, Azomycin, antitumor antibiotics FR901463, and Karalicin. Most of them are produced by the genus Pseudomonas such as Pseudomonas fluorescens and Pseudomonas aeruginosa. These antibiotics are known to possess antiviral, antimicrobial, insect and mammalian antifeedant, antihelminthic, phytotoxic, antioxidant, cytotoxic, antitumor, and PGP activities (Hammer et al., 1997). Moreover antibiotics released by the PGPR are thought to be one of the major possible mechanism employ by the antagonists against phytopathogens (Glick et $a l ., 2007)$. The reduction in take all disease of wheat (Gaeumannomyces graminis f.sp tritici) and wilt (Fusarium oxysporium) is due to colonization of Pseudomonads producing phenazine through their redox activity (ChinA-Woeng et al., 2003).The antibiotic, pyrrolnitrin produce by BL 915 strain of Pseudomonas fluorescens against Rhizoctonia solani manage damping-off of cotton plants (Hill et al., 1994). Another antibiotic, DAPG (2,4-Diacetyl Phloroglucinol) produce by pseudomonads, disrupt the membrane and inhibit the zoospore of Pythium (de Souza et al., 2003).

\section{ACC (1-aminocyclopropane-1-carboxylic acid) deaminase activity}

Apart from the major function of ethylene, ripening, an over production under stress condition (Abeles et al., 1992; Arshad and Frankenberger, 2002; Etesami et al., 2015; Jha and Saraf, 2015) result in inhibitory effect on root growth. To combat this situation, an interesting phenomenon is exhibited by PGPR which perform ACC deaminase activity, regulating this important hormone and thus modulating the growth and development of plant (Arshad and Frankenberger, 2002; Glick, 2005). PGPR convert SAM (Sadenosylmethionine) to ACC by the enzymes ACC synthetase which is activated through production of IAA. Moreover, the ACC release by the root exudates are taken by the microorganism as a source of nitrogen and are further converted into ammonia and $\alpha$ ketobutyrate by bacterial ACC deaminase activity which checks the production of ethylene. Therefore, in this way, ACC deaminase producing PGPR act as soldier against the adverse effect of ethylene under stress condition (Glick, 2014). ACC deaminase activity performing microbes bind non-specifically to a wide range of plant surfaces as compared to those which have less ACC deaminase activity (Glick, 2005).

ACC deaminase are possessed by a range of microbes including gram negative bacteria 
(Babalola et al., 2003), gram positive bacteria (Belimov et al., 2001; Ghosh et al., 2003), rhizobia (Ma et al., 2003). PGPR such as Azospirillum lipoferum (Blaha et al., 2006), Bacillus (Belimov et al., 2001), Pseudomonas (Belimov et al., 2001; Blaha et al., 2006; Hontzeaset et al., 2004), Ralstonia solanacearum (Blahaet al., 2006), Rhizobium
(Ma et al., 2003; Uchiumi et al., 2004) are actively involved in ACC deaminase activity. These ACC deaminases containing PGPR are fascinating researcher to exploit them at molecular level through genetic manipulation (Belimov et al., 2002; Safronova et al., 2006; Sergeeva et al., 2006) and thus creating a vision to utilize them more precisely.

Fig.1 Mechanism of PGPR

PROTECTS PLANTS FROM ABIOTIC
STRESSES
•Modulation in the level of plant stress
markers
-Peroxidases
-Superoxide dismutase
-Polyphenol oxidase
-ACC deaminase activity

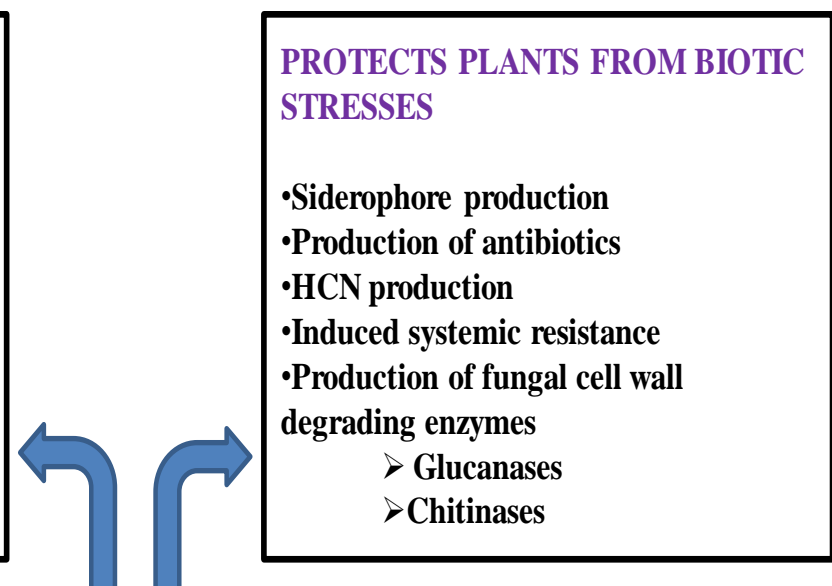

\section{Mechanism of PGPR}

PROVIDING NUTRIENTS TO PLANTS

-Symbiotic and non-symbiotic nitrogen

fixation

-Production of phytohormones

$>$ Indole acetic acid

$>$ Cytokinins

$>$ Gibberellins

- Solubilization of phosphate and minerals 
Fig.2 Schematic representation of solubilization of soil phosphorous by PGPR

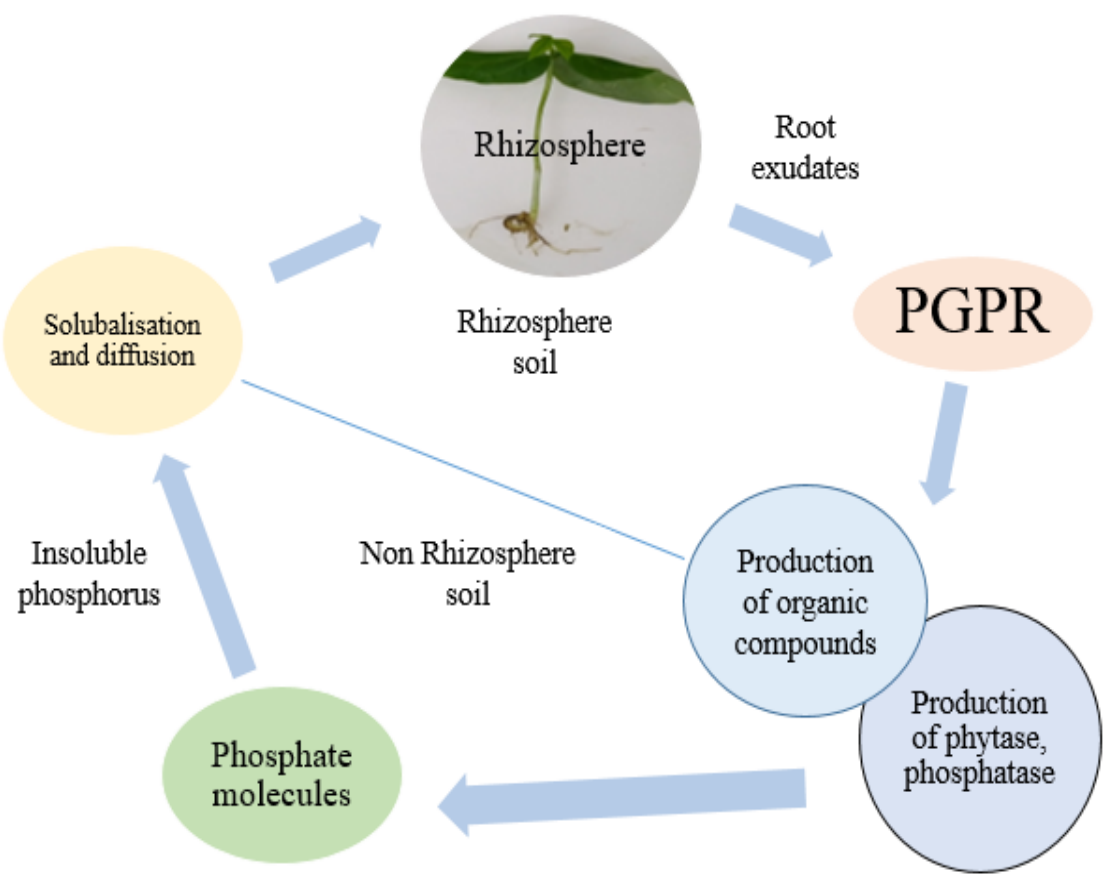

Fig.3 Signal transduction pathways leading to pathogen induced systemic acquired resistance (SAR) and rhizobacteria-mediated induced systemic resistance (ISR) in Arabidopsis thaliana (Van Loon et al., 1998).
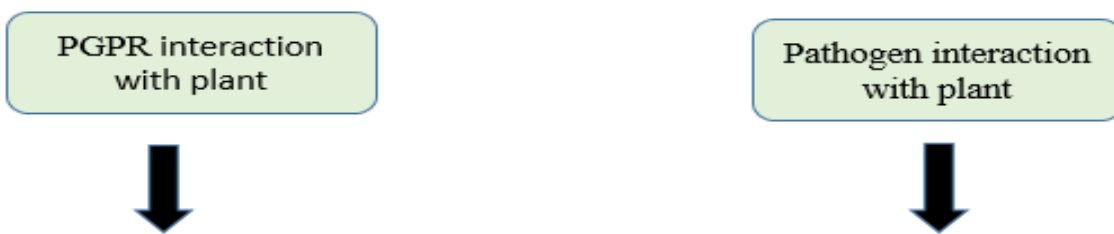

Jasmonic acid ethylene response

Salicylic acid response
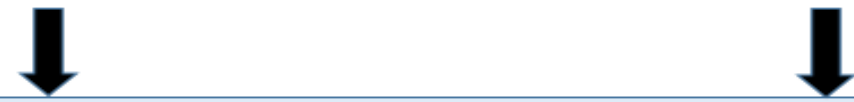

Positive regulatory protein NPR 1 interact with TGA transcription factor 
PGPR produces a wide range of low molecular weight metabolites with antifungal activity. Some Pseudomonads can synthesize hydrogen cyanide to which these pseudomonads are themselves resistant, a metabolite that has been linked to the ability of those strains to inhibit some pathogenic fungi.

\section{Induced Systemic Resistance}

The non-pathogenic PGPR activates Induced systemic resistance which operates to several pathogens simultaneously, thus proving resistance to wide range of pathogens (Figure 3). Rhizobacteriain the plant roots produce signal, which spreads systemicallywithin the plant and increases the defensive capacity of the distant tissuesfrom the subsequent infection by the pathogens(Thakker et al., 2011). Pseudomonas and Bacillus spp. are the rhizobacteria most studied that trigger ISR (Kloepper et al., 2006).

In conclusion, sustainable agriculture is the need of the world as of late due to the unfavourable impact of synthetic substances utilized in farming. In the present situation, using PGPR in agriculture are one of the most appropriate decisions for plant development advancement so as to mitigate various sorts of stresses which are experienced by the plants and also to conquer the utilization of synthetic composts and pesticides. The rhizosphere is a huge supply of organisms, where PGPRs are most generally found and are involved in overall well being of the plant. The exudates of plant roots generally collaborates them and help in root-colonizing activities. For that reason, PGPR is considered as 'A gift of nature for bright future'. PGPR and their interactions with plants are exploited commercially (Podile and Kishore, 2006) and can be a huge future scope for sustainable agriculture. These noble and beneficial creatures have been introduced in several crops like maize, wheat, oat, barley, peas, canola, soya, potatoes, tomatoes, lentils, radicchio and cucumber (Gray and Smith, 2005). Thus, PGPR offers an excellent attractive alternative to chemicals and can maintain or even increase the yield of crop which is the need of time.

\section{References}

Abeles, FB., Morgan, PW., and Saltveit, ME. 1992. Ethylene in Plant Biology. Academic Press, San Diego. 414p.

Aeron, A., Kumar, S., Pandey, P., and Maheshwari, DK. 2011. Emerging role of plant growth promoting rhizobacteria in agrobiology. In D. K. Maheshwari (Ed.), Bacteria in agrobiology: Crop ecosystems Springer Berlin Heidelberg. pp. 1-36.

Andrade, G., Mihara, KL., Linderman, RG., and Bethlenfalvy, GJ. 1997. Bacteria from rhizosphere and hydrosphere soils of different arbuscular - mycorrhizal fungi. Plant and soil. 192(1):71-79.

Antoun, H., and Prevost, D. 2006. Ecology of plant growth promoting rhizobacteria. In Z.A. Siddiqui (Ed.), PGPR: Biocontrol and biofertilization Springer Netherlands. pp. 1-38.

Arshad, M., and Frankenberger, WT. 2002. Ethylene: agricultural sources and applications. Kluwer Academic / Plenum Publishers, New York.

Aseri, GK., Jain, N., and Tarafdar, JC. 2009. Hydrolysis of organic phosphate forms by phosphatases and phytase producing fungi of arid and semi-arid soils of India. American - Eurasian Journal of Agriculture and Environmental Sciences. 5: 564-570.

Babalola, OO., Osir, EO., Sanni, AI., Odhaimbo, GD., and Bulimo, WD. 2003. Amplification of 1-aminocyclopropane-1-carboxylic (ACC) deaminase from plant growth promoting 
rhizobacteria in Striga-infested soil. Afr J Biotechnol. 2:157-160.

Bashan, Y., and Holguin, G. 1998. Proposal for the division of plant growthpromoting rhizobacteria into two classifications: Biocontrol-PGPB (plant growth-promoting bacteria) and PGPB. Soil Biology and Biochemistry. 30:1225-1228.

Belimov, AA., Safronova, VI., and Mimura, T. 2002. Response of spring rape (Brassica napus var. oleifera L.) to inoculation with plant growth promoting rhizobacteria containing 1aminocyclopropane- 1-carboxylate deaminase depends on nutrient status of the plant. Can J Microbiol/Rev Can Microbiol. 48:189-199.

Belimov, AA., Safronova, VI., Sergeyeva, TA., Egorova, TN., Matveyeva VA., Tsyganov, VE., Borisov, AY., Tikhonovich, IA., Kluge, C., Preisfeld, A., Dietz, KJ., and Stepanok, VV. 2001. Characterization of plant growth promoting rhizobacteria isolated from polluted soils and containing 1aminocyclopropane-1-carboxylate deaminase. Can J Microbiol. 47:242252.

Bhattacharyya, PN., and Jha, DK. 2012. Plant growth-promoting rhizobacteria (PGPR): Emergence in agriculture. World Journal of Microbiology and Biotechnology. 28:1327-1350.

Blaha, D., Combaret, CP., Mirza MS., and Loccoz, YM. 2006. Phylogeny of the 1aminocyclopropane-1-carboxylic acid deaminase-encoding gene acdS in phytobeneficial and pathogenic Proteobacteria and relation with strain biogeography. FEMS Microbiol Ecol. 56(3):455-470.

Bringhurst, RM., Cardon, ZG., and Gage, DJ. 2001. Galactosides in the rhizosphere: utilization by Sinorhizobium meliloti and development of a biosensor. Proc
Natl Acad Sci USA 98(8):4540-4545.

Broughton, WJ., Jabbouri, Saïd., and Perret, Xavier. 2000. Keys to Symbiotic Harmony. J. Bacteriol. 182(20):56415652.

Chet, I., and Inbar, J. 1994. Biological control of fungal pathogens. Appl Biochem Biotechnol. 48(1):37-43.

Chin-A-Woeng, TF., Bloemberg, GV., and Lugtenberg, BJ. 2003. Phenazines and their role in biocontrol by Pseudomonas bacteria. New Phytologist. 157:503-523.

Compant, S., Dufy, B., Nowak, J., Clement, C., and Barka, EA. 2005. Use of plant growth-promoting bacteria for biocontrol of plant diseases: Principles, mechanisms of action, and future prospects. Appl Environ Microbiol. 71(9):4951-4959.

de Souza, JT., Arnould, C., Deulvot, C., Lemanceau, P., Gianinazzp-Pearson, V., and Raaijmakers, JM. 2003. Effect of 2,4-Diacetyl Phloroglucinol on Pythium: Cellular responses and variation in sensitivity among propagules and species. Phytopathology. 93(8): 966-975.

Etesami, H., Alikhani, HA., and Hosseini, HM. 2015. Indole-3-acetic acid and 1aminocyclopropane-1-carboxylate deaminase: Bacterial traits required in rhizosphere rhizoplane and/or endophytic competence by beneficial bacteria. In D. K. Maheshwari (Ed.), Bacterial metabolites in sustainable agroecosystem Springer International. 12:183-258.

Fisher, MC., Henk, DA., Briggs, CJ., Brownstein, JS., Madoff, LC., McCraw, SL., and Gurr, SJ. 2012. Emerging fungal threats to animal, plant and ecosystem health. Nature. 484:186-194.

Ghosh, S., Penterman, JN., Little, RD., Chavez, R., and Glick, BR. 2003. Three newly isolated plant growth-promoting bacilli facilitate the seedling growth of 
canola, Brassica campestris. Plant Physiol Biochem. 41:277-281.

Glick, BR. 1995. The enhancement of plant growth by free-living bacteria. Can J Microbiol. 41(2):109-117.

Glick, BR. 2005. Modulation of plant ethylene levels by the bacterial enzyme ACC deaminase. FEMS Microbiol Lett. 251(1):1-7.

Glick, BR. 2014. Bacteria with ACC deaminase can promote plant growth and help to feed the world. Microbiol. Res. 169(1):30-39.

Glick, BR., Cheng, Z., Czarny, J., and Duan, J. 2007. Promotion of plant growth by ACC deaminase-producing soil bacteria. In: Bakker PAHM., Raaijmakers J.M., Bloemberg G., Höfte M., Lemanceau P., Cooke BM. (eds) New Perspectives and Approaches in Plant Growth-Promoting Rhizobacteria Research. Springer, Dordrecht. pp.329339.

Goswami, D., Dhandhukia, P., Patel, P., and Thakker, JN. 2014. Screening of PGPR from saline desert of Kutch: Growth promotion in Arachis hypogea by Bacillus licheniformis A2. Microbiol. Res. 169(1): 66-75.

Goswami, D., Parmar, S., Vaghela, H., Dhandhukia, P., and Thakker, J. 2015. Describing Paenibacillus mucilaginosus strain N3 as an efficient plant growth promoting rhizobacteria (PGPR). Cogent Food \& Agriculture. 1(1).

Goswami, D., Pithwa, S., Dhandhukia, P., and Thakker, JN. 2014. Delineating Kocuria turfanensis 2M4 as a credible PGPR: A novel IAA-producing bacteria isolated from saline desert. J Plant Interact. 9(1): 566-576.

Govindasamy, V., Senthilkumar, M., Magheshwaran, V., Kumar, U., Bose, P., Sharma, V., and Annapurna, K. 2011. Bacillus and Paenibacillus spp.: Potential PGPR for sustainable agriculture. In: Maheshwari D. (eds) Plant Growth and Health Promoting Bacteria. Microbiology Monographs, Springer, Berlin, Heidelberg. 18:333364.

Gray, EJ., and Smith, DL. 2005. Intracellular and extracellular PGPR: commonalities and distinctions in the plant-bacterium signaling processes. Soil Biol Biochem. 37(3): 395-412.

Haas, D., and Défago, G. 2005. Biological control of soil-borne pathogens by fluorescent pseudomonads. Nat. Rev. Microbiol. 3:307-319.

Hammer, PE., Hill, DS., Lam, ST., Van Pée, KH., and Ligon, JM. 1997. Four genes from Pseudomonas fluorescens that encode the biosynthesis of pyrrolnitrin. Appl. Environ. Microbiol. 63(6): 21472154.

Han, HS., and Lee, KD. 2006. Efect of coinoculation with phosphate and potassium solubilising bacteria on mineral uptake and growth of pepper and cucumber. Plant Soil Environ. 52(3):130-136.

Hedden, P., and Phillips, AL. 2000. Gibberellin metabolism: New insights revealed by the genes. Trends Plant Sci. 5(12):523-530.

Heulin, T., Achouak, W., Berge, O., Normand, P., and Guinebretière, $\mathrm{MH}$. 2002. Paenibacillus graminis sp. nov. and Paenibacillu sodorifer sp. nov., isolated from plant roots, soil and food. International Journal of Systematic and Evolutionary Microbiology. 52(2):607616.

Hider, RC., and Kong, X. 2010. Chemistry and biology of siderophores. Natural products reports. 27(5):637-657.

Hill, DS., Stein, JI., Torkewitz, NR., Morse, AM., Howell, CR., Pachlatko, JP., Becker, JO., and Ligon, JM. 1994. Cloning of genes involved in the synthesis of pyrrolnitrin from 
Pseudomonas fluorescens and role of pyrrolnitrin synthesis in biological control of plant diseases. Appl Environ Microbiol. 60(1):78-85.

Hiltner, L. 1904. Uber neuereErfahrungen and Probleme auf demGebiete der BodenbakteriologieunterbesondererBer ucksichtigung der Grundungung und Brache. Arb DLG. 98:59-78.

Hontzeas, N., Zoidakis, J., Glick, BR., and Abu-Omar, MM. 2004. Expression and characterization of 1aminocyclopropane-1-carboxylate deaminase from the rhizobacterium Pseudomonas putida UW4: a key enzyme in bacterial plant growth promotion. BBA-Proteins Proteom. 1703(1):11-19.

Jha, CK., and Saraf, M. 2015. Plant growth promoting rhizobacteria (PGPR): A review. E3 Journal of Agricultural Research and Development. 5(2):108119.

Jha, CK., Patel, B., and Saraf, M. 2012. Stimulation of the growth of Jatropha curcas by the plant growth promoting bacterium Enterobacter cancerogenus MSA2. World J Microbiol Biotechnol. 28:891-899.

Jha, CK., Patel, D., Rajendran, N., and Saraf, M. 2010. Combinatorial assessment on dominance and informative diversity of PGPR from rhizosphere of Jatropha curcas L. J. Basic Microbiol. 50(3): 211-217.

Kloepper, JW., and Ryu, Choong-Min. 2006. Bacterial endophytes as elicitors of induced systemic resistance. In: Schulz B.J.E., Boyle C.J.C., Sieber T.N. (eds) Microbial Root Endophytes. Soil Biology, Springer, Berlin, Heidelberg. 9:33-52.

Kloepper, JW., and Schroth, MN. 1978. Plant growth-promoting rhizobacteria on radishes. In Proceedings of the $4^{\text {th }}$ International Conference on Plant
Pathogenic Bacteria. 2:879-882.

Kucey, RMN., Janzen, HH., and Leggett, ME. 1989. Microbially mediated increases in plant-available phosphorus. Adv. Agron. 42:199-228.

Ma, W., Sebestianova, SB., Sebestian, J., Burd, GI., Guinel, FC., and Glick, BR. 2003. Prevalence of 1aminocyclopropane-1-carboxylate deaminase in Rhizobium spp. Antonie Leeuwenhoek. 83:285-291.

Maheshwari, DK., Dheeman, S., and Agarwal, M. 2015. Phytohormoneproducing PGPR for sustainable agriculture. In D. K. Maheshwari (Ed.), Bacterial metabolites in sustainable agroecosystem, Springer International. 12:159-182.

Maougal, RT., Brauman, A., Plassard, C., Abadie J., Djekoun, A., and Drevon, JJ. 2014. Bacterial capacities to mineralize phytate increase in the rhizosphere of nodulated common bean (Phaseolus vulgaris) under $\mathrm{P}$ deficiency. Eur. J. Soil Biol. 62: 8-14.

Martinez - Viveros, O., Jorquera, MA., Crowley, DE., Gajardo, GMLM., and Mora, ML. 2010. Mechanism and practical considerations involved in plant growth promotion by rhizobacteria. J. Soil Sci. Plant Nutr. 10(3): 293-319.

Nadeem, SM., Ahmad, M., Zahir, ZA., Javaid, A., and Ashraf, M. 2014. The role of mycorrhizae and plant growth promoting rhizobacteria (PGPR) in improving crop productivity under stressful environments. Biotechnol. Adv. 32(2):429-448.

Oberson, A., Frossard, E., Bühlmann, C., Mayer, J., Mäder, P., and Lüscher, A. 2013. Nitrogen fixation and transfer in grass-clover leys under organic and conventional cropping systems. Plant and Soil. 371(1):237-255.

Patten, CL., and Glick, BR. 1996. Bacterial 
biosynthesis of indole-3-acetic acid. Can. J. Microbiol. 42(3):207-220.

Perret, Xavier., Staehelin, Christian., and Broughton, WJ. 2000. Molecular Basis of Symbiotic Promiscuity. Microbiol. Mol. Biol. Rev. 64(1):180-201.

Podile, AR., and Kishore, GK. 2006. Plant growth-promoting rhizobacteria. In: Gnanamanickam SS, editor. PlantAssociated Bacteria. Springer; Netherlands: pp.195-230.

Pradhan, N., and Shukla, LB. 2006. Solubilization of inorganic phosphates by fungi isolated from agriculture soil. Afr. J. Biotechnol. 5(10):850-854.

Ramos-Solano, B., Barriuso, J., and Gutiérrez-Mañero, $\quad 2008$. Physiological and molecular mechanisms of plant growth promoting rhizobacteria (PGPR). In I. Ahmad, J. Pichtel, \& S. Hayat (Eds.), Plantbacteria interactions: Strategies and techniques to promote plant growth. pp.41-54.

Safronova, VI., Stepanok, VV., Engqvist, GL., Alekseyev, YV., and Belimov, AA. 2006. Root-associated bacteria containing 1-aminocyclopropane- 1carboxylate deaminase improve growth and nutrient uptake by pea genotypes cultivated in cadmium supplemented soil. Biol Fert Soils. 42:267-272.

Salisbury, FB. 1994. The role of plant hormones. In R. E. Wilkinson (Ed.), Plant-environment interactions. pp.3981.

Seldin, L., Van Elsas, JD., and Penido, EGC. 1984. Bacillus azotoxans sp. nov., a nitrogen-fixing species from Brazilian soils and grass roots. Int $\mathbf{J}$ Syst Bacteriol. 34(4):451-456.

Sergeeva, E., Shah, S., and Glick, BR. 2006. Growth of transgenic canola (Brassica napus cv. Westar) expressing a bacterial 1-aminocyclopropane- 1-carboxylate (ACC) deaminase gene on high concentrations of salt. World $\mathbf{J}$ Microbiol Biotech. 22: 277-282.

Sgroy, V., Cassán, F., Masciarelli, O., Del Papa, MF., Lagares, A., and Luna, V. 2009. Isolation and characterization of endophytic plant growth-promoting (PGPB) or stress homeostasisregulating (PSHB) bacteria associated to the halophyte Prosopis strombulifera. Appl Microbiol Biotechnol. 85(2):371381.

Shen, X., Hu, H., Peng, H., Wang, W., and Zhang, X. 2013. Comparative genomic analysis of four representative plant growthpromoting rhizobacteria in Pseudomonas. BMC Genomics. 14:271. Siddikee, MA., Chauhan, PS., Anandham, R., Han, GH., and Sa, T. 2010. Isolation, characterization, and use for plant growth promotion under salt stress, of ACC deaminase-producing halotolerant bacteria derived from coastal soil. J. Microbiol. Biotechnol. 20(11):15771584.

Sivasakthi, S., Usharani, G., and Saranraj, P. 2014. Biocontrol potentiality of plant growth promoting rhizobacteria (PGPR) - Pseudomonas flurorescens and Bacillus subtilis: A review. Afr. J. Agric. Res. 9(16):1265-1277.

Someya, N., Kataoka, N., Komagata, T., Hirayae, K., Hibi, T., and Akutsu, K. 2000. Biological control of cyclamen soilborne diseases by Serratia marcescens strain B2. Plant Dis. 84(3):334-340.

Spaepen, S., Vanderleyden, J., and Remans, R. 2007. Indole-3-acetic acid in microbial and microorganism-plant signaling. FEMS Microbiol. Rev. 31:425-448.

Stacey, G., Burris, RH., and Evans, HJ. (Eds.).1992. Biological nitrogen fixation. Berlin: Springer Science \& Business Media.

Tarafdar, JC., and Classen, N. 1988. Organic 
phosphorous compounds as a phosphorous source for higher plants through the activity of phosphatases produced by plant roots and microorganisms. Biol Fert Soils. 5:308312.

Tarafdar, JC., Rao AV., and Bala, K. 1988. Production of phosphates by fungi isolated from dessert soils. Folia Microbiol. 33: 453-457.

Thakker, JN., Patel, P., and Dhandhukia, PC. 2011. Induction of defence-related enzymes in susceptible variety of banana: Role of Fusarium - derived elicitors. Arch Phytopathology Plant Protect. 44(20):1976-1984.

Uchiumi, T., Oowada, T., Itakura, M., Mitsui, H., Nukui, N., Dawadi, P., Kaneko, T., Tabata, S., Yokoyama, T., Tejima, T., Saeki, K., Oomori, H., Hayashi, M., Maekawa, T., Sriprang, R., Murooka, Y., Tajima, S., Simomura, K., Nomura, M., Suzuki, A., Shimoda, S., Sioya, K., Abe, M., and Minamisawa, K. 2004. Expression islands clustered on symbiosis island of Mesorhizobium loti genome. J Bacteriol. 186:2439-2448. van Loon, LC., Bakker, PAHM., and Pieterse, CMJ. 1998. Systemic resistance induced by rhizosphere bacteria. Annu. Rev. Phytopathol. 36:453-483.

Vessey, JK. 2003. Plant growth promoting rhizobacteria as biofertilizers. Plant Soil. 255:571-586.

Von der Weid, I., Duarte, GF., van Elsas, JD., and Seldin, L. 2002. Paenibacillus brasilensis sp. nov., a novel nitrogenfixing species isolated from the maize rhizosphere in Brazil. Int $\mathbf{J}$ Syst Evol Microbiol. 52(6): 2147-2153.

Wang, ET., and Martinez - Romero, E. 2000. Sesbania herbacea - Rhizobium huautlense nodulation in flooded soils and comparative characterization of $S$. herbacea- nodulating rhizobia in different environments. Microb Ecol. 40:25-32.

Yadav, RS., Tarafdar, JC. 2003. Phytase and phosphatase producing fungi in arid and semi- arid soils and their efficiency in hydrolyzing different organic $\mathrm{P}$ compounds. Soil Biol. Biochem. 35(6): 745-751.

\section{How to cite this article:}

Anshu Kumar, Ritesh Kumar, Mamta Kumari and Suraj Goldar. 2020. Enhancement of Plant Growth by Using PGPR for a Sustainable Agriculture: A Review. Int.J.Curr.Microbiol.App.Sci. 9(02): 152-165. doi: https://doi.org/10.20546/ijcmas.2020.902.019 